- caused by the disappearance of the Harvard legal bibliographies will be filled by another publication-equally prestigious and perhaps more efficient.

\title{
JOURNAL OF LEGAL PLURALISM
}

In order to broaden the scope of its subject-matter, the African Law Studies is being renamed the Journal of Legal Pluralism. The new journal is bilingual: English and French. For further information write to:

John Griffiths

Editor-in-Chief

Juridish Instituut

Turftorenstraat 13

9712 BM Groninjen

THE NETHERLANDS.

\section{NEW INTERNATIONAL LAW REVIEW}

IPRax (Praxis des internationalen Privat-und Verfahrensrechts) is a new German-language law review specializing entirely in the subjectarea of conflict of laws (or private international law). Published six times a year since January, 1981, it contains short articles, reports, notes and comments about German and European Communities current conflict of laws developments. In view of their strong impact on traditional conflict rules, careful attention is also paid to the practical expansion of such international agreements as, for example, the EEC convention on the recognition of jurisdictions and judgments in commercial matters, the UNCITRAL convention on international sales, and the Hague family law conventions. Case notes discuss not only German court decisions but also relevant opinions of the European Communities Court of Justice, which is becoming increasingly involved in conflict of laws situations.

The new law review is edited by Professors Karl Firsching, Dieter Henrich, Bernd von Hoffman and Erik Jayme, who are all well-known conflict of laws specialists in Germany. It is published by the Gieseking Verlag in Bielefeld, Federal Republic of Germany. The current annual subscription is DM 114.

\section{INTERNATIONAL LAWYERS' NEWSLETTER}

This extraordinary newsletter, written primarily for international business lawyers with extensive travel itineraries, does not confine itself to the usual short notes or reports about new international legal develop- 